\title{
Lap Shear Strength of Selected Adhesives (Epoxy, Varnish, B-Stage Glass Cloth) in Liquid Nitrogen and at Room Temperature
}

\author{
K. J. Froelich \\ C. M. Fitzpatrick
}

\section{OAK RIDGE NATIONAL LABORATORY}

OPERATED BY UNION CARBIDE CORPORATION FOR THE ENERGY RESEARCH AND DEVELOPMENT ADMINISTRATION 


\section{DISCLAIMER}

This report was prepared as an account of work sponsored by an agency of the United States Government. Neither the United States Government nor any agency Thereof, nor any of their employees, makes any warranty, express or implied, or assumes any legal liability or responsibility for the accuracy, completeness, or usefulness of any information, apparatus, product, or process disclosed, or represents that its use would not infringe privately owned rights. Reference herein to any specific commercial product, process, or service by trade name, trademark, manufacturer, or otherwise does not necessarily constitute or imply its endorsement, recommendation, or favoring by the United States Government or any agency thereof. The views and opinions of authors expressed herein do not necessarily state or reflect those of the United States Government or any agency thereof. 


\section{DISCLAIMER}

Portions of this document may be illegible in electronic image products. Images are produced from the best available original document. 


\section{Printed in the United States of America. Available from}

National Technical Information Service

U.S. Department of Commerce 5285 Port Royal Road, Springfield, Virginia 22161

Price: Printed Copy $\$ 4.00$; Microfiche $\$ 3.00$

This report was prepared as an account of work sponsored by the United States Government. Neither the United States nor the Energy Research and Development Administration/United States Nuclear Regulatory Commission, nor any of their employees, nor any of their contractors, subcontractors, or their employees, makes any warranty, express or implied, or assumes any legal liability or responsibility for the accuracy, completeness or usefulness of any information, apparatus, product or process disclosed, or represents that its use would not infringe privately owned rights. 
Contract No. W-7405-eng-26

FUSION ENERGY DIVISION

LAP SHEAR STRENGTH OF SELECTED ADHESIVES (EPOXY, VARNISH, B-STAGE GLASS CLOTH) IN LIQUID NITROGEN AND AT ROOM TEMPERATURE

K. J. Froelich and C. M. Fitzpatrick Magnetics and Superconductivity Section

Date Published: December 1976

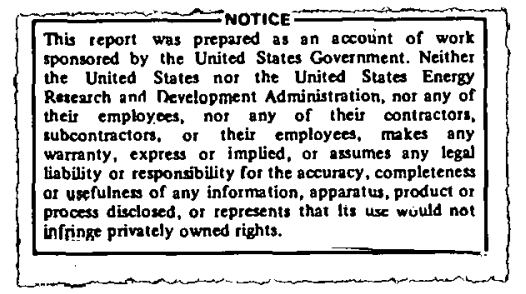

NOTICE This document contains information of a preliminary nature. It is subject to revision or correction and therefore does not represent a final report.

\author{
Prepared by the \\ OAK RIDGE NATIONAL LABORATORY \\ Oak Ridge, Tennessee 37830 \\ operated by \\ UNION CARBIDE CORPORATION \\ for the \\ ENERGY RESEARCH AND DEVELOPMENT ADMINISTRATION
}


LAP SHEAR STRENGTH OF SELECTED ADHESIVES (EPOXY, VARNISH, B-STAGE GLASS CLOTH) IN LIQUID NITROGEN AND AT ROOM TEMPERATURE

K. J. Froelich and C. M. Fitzpatrick

\section{ABSTRACT}

The lap shear strengths of several adhesives were measured in liquid nitrogen and at room temperature. The adhesives included several epoxy resins, a varnish; and a B-stage glass cloth (a partially cured resin in a fiberglass cloth matrix). Several parameters critical to bond strength were varied: adhesive and adherend differences, surface preparation, coupling agents, glass cloth, epoxy thickness, fillers, and bonding pressure and temperature. The highest lap shear strengths were obtained with the B-stage glass cloth at both liquid nitrogen and room temperatures with values of $\sim 20 \mathrm{MPa}(3000 \mathrm{psi})$ and $\sim 25.5 \mathrm{MPa}(3700 \mathrm{psi})$ respectively.

\section{INTRODUCTION}

Adhesives will be used in future superconducting machinery for electrical insulation and/or structural strength. The application of the adhesive, whether for structural support, spacing, thermal insulation, or electrical insulation, will determine just how strong the adhesive must be. Our particular application of an adhesive is to provide good mechanical strength and electrical insulation between turns or layers of the superconducting coils to be fabricated for tokamak type fusion machines. For that purpose, a program was initiated by the Materials Evaluation Group of the Superconducting Magnet Development Program to evaluate the lap shear strengths of selected adhesives at room and at liquid nitrogen temperatures. Liquid nitrogen was chosen over liquid helium because of the difficulties and expense of liquid helium testing and also hecause the mechanical and physical properties of the adherends and adhesives change 1 ittle from $77 \mathrm{~K}$ to $4.2 \mathrm{~K}$.

The purpose of the lap shear tests was to quantify and compare the effects on shear strength induced by several parameters: adhesive and adherend differences, surface preparations, coupling agents, glass cloth, adhesive thickness, fillers, and curing pressure and temperature. The 
comparison yielded the best adhesive, of the ones tested, for use at room temperature and/or liquid nitrogen. The best adhesive was determined in relation to winding a large coil: i.e., ease in adhesive application, surface preparation of conductor, working setup time of the adhesive, curing temperature and cycle, and overall mechanical. strength.

The adhesives were subdivided into two groups, epoxies and B-stage glass cloth, because of the two distinct methods of sample fabrication with respect to surface preparation, temperature and pressure cure cycles, adhesive application, and adherend type and size.

\section{EPOXIES}

The several epoxies used in the shear strength evaluation are listed in Table 1 (which indicates the epoxy trade name, manufacturer, mixture ratios, typical setup time, cure cycle, and relative viscosity). The Shell Epon, Emerson and Cummings Stycast, and General Mills Versamid epoxies were less than one year old by the time the samples were tested, whereas the Hexcel Uralite, Epotek, and Crest epoxies were mixed and tested slightly after the expiration date of the shelf lifc. The effect of aging on shear strength should be minimal, particularly since the epoxies had been stored in a refrigerator.

A large percentage of the epoxies tested was a mixture of $70 \%$ Epon 871 , 30\%. Epon 828, and 13 pph Epon $\mathrm{Z}$ curing agent hecause this particular mixture had been used in the study of the effect. of surfare preparation on shear strength. This particular mixture was optimized for cryogenic use by the addition of the flexibilizer Epon 871 (an aliphatic epoxy resin), to the Epon 828 (an unmodified bisphenol an epoxy resin). The proportion of $70 \%$ Epon $871,30 \% 828$, and $13 \mathrm{pph}$ Epon $\mathrm{Z}$ curing agent had the highest overall strength in our cryogenic tensile and impact tests of the 871-828 group and was therefore used for the shear tests. This Epon 871-828 mixture was easily mixed, outgassed, and poured, and it lends. itself to vacuum coil encapsulation applications. Setup time is long - over 5 hours a $75^{\circ} \mathrm{F}$ - and the cure cycle is mild - about $150^{\circ} \mathrm{F}$ for 24 hours. 
Table 1.

\begin{tabular}{|c|c|c|c|c|c|}
\hline $\begin{array}{c}\text { Epoxy } \\
\text { Trade Name }\end{array}$ & Manufacturer & $\begin{array}{l}\text { Mixing } \\
\text { Ratio }\end{array}$ & $\begin{array}{c}\text { Typical } \\
\text { Setup Time }\end{array}$ & $\begin{array}{l}\text { Cure } \\
\text { Cycle }\end{array}$ & Viscosity \\
\hline $\begin{array}{l}\text { Epon } 871 \\
\text { Epon } 828 \\
\text { Z-Hardener }\end{array}$ & $\begin{array}{l}\text { She11 } \\
\text { She11 } \\
\text { Shell }\end{array}$ & $\begin{array}{l}871-70 \% \\
828-30 \% \\
z-13 p p h\end{array}$ & $\begin{array}{l}\sim 5 \mathrm{hrs} @ 75^{\circ} \mathrm{F} \\
\sim 2 \mathrm{hrs} @ 150^{\circ} \mathrm{F}\end{array}$ & $24 \mathrm{hrs} @ 150^{\circ} \mathrm{F}$ & Thin \\
\hline $\begin{array}{l}\text { Epon } 871 \\
\text { Epon } 828 \\
\text { Z-Hardener } \\
\text { Silane } 6020\end{array}$ & $\begin{array}{l}\text { Shell } \\
\text { Shell } \\
\text { Shell } \\
\text { Dow Corning }\end{array}$ & $\begin{array}{l}871-70 \% \\
828-30 \% \\
z-13 p p h \\
.5 \% / w t\end{array}$ & $\begin{array}{l}\sim 5 \mathrm{hrs} @ 75^{\circ} \mathrm{F} \\
\sim 2 \mathrm{hrs} @ 150^{\circ} \mathrm{F}\end{array}$ & $24 \mathrm{hrs} @ 150^{\circ} \mathrm{F}$ & Thin \\
\hline $\begin{array}{l}\text { Stycast } 2850 \\
\text { FT (Blue) } \\
24 \text { LV Hardener }\end{array}$ & $\begin{array}{l}\text { Emerson \& } \\
\text { Cummings }\end{array}$ & $\begin{array}{l}\text { Stycast } 2850 \mathrm{FT} \\
100 \% \\
24 \mathrm{LV}-7 \mathrm{pph}\end{array}$ & $1 \mathrm{hr} @ 75^{\circ} \mathrm{F}$ & $24 \operatorname{hrs} @ 75^{\circ} \mathrm{F}$ & $\begin{array}{l}\text { Med. Thick } \\
\sim 15,000 \mathrm{CPS} \\
070^{\circ} \mathrm{F}\end{array}$ \\
\hline $\begin{array}{l}\text { Stycast } 2850 \\
\text { FT (Black) } \\
\text { \#9 Hardener }\end{array}$ & $\begin{array}{l}\text { Emerson \& } \\
\text { Cummings }\end{array}$ & $\begin{array}{l}\text { Stycast } 2850 \text { FT } \\
100 \% ; \text { \# } 9 \text { Hardener } \\
3.5 \mathrm{pph}\end{array}$ & $1 \mathrm{hr} @ 75^{\circ} \mathrm{F}$ & $24 \mathrm{hrs} @ 75^{\circ} \mathrm{F}$ & $\begin{array}{l}\text { Thick } \\
90,000 \mathrm{CPS} \\
970^{\circ} \mathrm{F}\end{array}$ \\
\hline $\begin{array}{l}\text { General Elec. } \\
\text { No. } 7031\end{array}$ & General Electric & $\begin{array}{l}\text { 100\% G.E. } \\
\text { Adhesive \& } \\
\text { insulating varnish }\end{array}$ & $\sim 6 \mathrm{hrs} @ 75^{\circ} \mathrm{F}$ & $\begin{array}{l}6 \text { hrse } 75^{\circ} \mathrm{F} \\
\text { plus } 12 \text { hrs } \\
\text { @ } 150^{\circ} \mathrm{F}\end{array}$ & Thin \\
\hline $\begin{array}{l}\text { Epon } 871 \\
\text { Epon } 828 \\
\text { Z-Hardener } \\
\text { Silane } 6040\end{array}$ & $\begin{array}{l}\text { Shell } \\
\text { Shell } \\
\text { Shell } \\
\text { Dow Corning }\end{array}$ & $\begin{array}{l}70 \%-871 \\
30 \%-828 \\
13 p p h-Z \\
.5 \% \text { Silane }\end{array}$ & $\begin{array}{l}\text { थ } \mathrm{hrs} @ 75^{\circ} \mathrm{F} \\
2 \mathrm{hrs} 150^{\circ} \mathrm{F} \\
\end{array}$ & $24 \mathrm{hrs} @ 150^{\circ} \mathrm{F}$ & Thin \\
\hline $\begin{array}{l}\text { Epon } 815 \\
\text { Versamid } 140\end{array}$ & $\begin{array}{l}\text { Shell } \\
\text { General Mills }\end{array}$ & $\begin{array}{l}100 \text { parts } \\
40 \text { parts }\end{array}$ & $4-6 \operatorname{hrs} @ 75^{\circ} \mathrm{F}$ & $24 \mathrm{hrs} @ 75^{\circ} \mathrm{F}$ & Thin \\
\hline Hexcel Uralite & Hexcel & $\begin{array}{l}100 \text { parts "A" } \\
40 \text { parts "B" }\end{array}$ & $\sim 10 \mathrm{~min}$. & $24 \mathrm{hrs} @ 150^{\circ} \mathrm{F}$ & Thick \\
\hline
\end{tabular}


Table I. (cont.)

\begin{tabular}{|c|c|c|c|c|c|}
\hline $\begin{array}{c}\text { Epoxy } \\
\text { Trade Name }\end{array}$ & Manufacturer & $\begin{array}{l}\text { Mixing } \\
\text { Ratio }\end{array}$ & $\begin{array}{c}\text { Typical } \\
\text { Setup Time }\end{array}$ & $\begin{array}{l}\text { Cure } \\
\text { CFcle }\end{array}$ & Viscosity \\
\hline Crest & Crest & $\begin{array}{l}100 \text { parts "A" } \\
26 \text { parts "B" } \\
\text { (by wt.) }\end{array}$ & $\sim 10 \mathrm{~min}$. & $2 \operatorname{hrs}\left(2250^{\circ} \mathrm{F}\right.$ & Thick \\
\hline $\begin{array}{l}\text { Epo-Tek } \\
920 \mathrm{FL}\end{array}$ & $\begin{array}{l}\text { Epoxy Technology } \\
\text { Inc. }\end{array}$ & $\begin{array}{l}100 \text { parts " } A \text { " } \\
3 \text { parts " } \mathrm{B} \text { " } \\
\text { (by wt.) }\end{array}$ & $\begin{array}{l}\text { In Excess } \\
\text { of } 8 \mathrm{hrs}\end{array}$ & $5 \min , 120^{\circ} \mathrm{F}$ & $\begin{array}{l}\text { Medium } \\
\text { Thick } \\
14,000 \text { CPS }\end{array}$ \\
\hline $\begin{array}{l}\text { Epon } 815 \\
\text { Versamid } 140 \\
\text { Silane } 6020\end{array}$ & $\begin{array}{l}\text { Shell } \\
\text { General Mills } \\
\text { Dow Corning }\end{array}$ & $\begin{array}{l}100 \text { parts } \\
40 \mathrm{pph} \\
1 \%\end{array}$ & $\begin{array}{l}5 \operatorname{hrs} @ 75^{\circ} \mathrm{F} \\
2 \operatorname{hrs} 150^{\circ} \mathrm{F}\end{array}$ & 24 hrse $150^{\circ} \mathrm{F}$ & Thin \\
\hline $\begin{array}{l}\text { Epon } 871 \\
\text { Epon } 828 \\
\text { Z-Hardener } \\
\text { Silane } 6020\end{array}$ & $\begin{array}{l}\text { Shell } \\
\text { Shell } \\
\text { Shel1 } \\
\text { Dow Corning }\end{array}$ & $\begin{array}{l}70 \%-871 \\
30 \%-828 \\
13 p p h-2 \\
1 \% \text { Silane }\end{array}$ & थ hrs@75 ${ }^{\circ} \mathrm{F}$ & $24 \mathrm{hrs} \theta 150^{\circ} \mathrm{F}$ & Thin \\
\hline $\begin{array}{l}\text { Epon } 815 \\
\text { Versamid } 140 \\
\text { Silane } 6020\end{array}$ & $\begin{array}{l}\text { Shell } \\
\text { General Mills } \\
\text { Dow Corning }\end{array}$ & $\begin{array}{l}100 \text { parts } \\
40 \mathrm{pph} \\
2 \%\end{array}$ & $4-6$ hrs@75 ${ }^{\circ} \mathrm{F}$ & $24 \mathrm{hrs} 375^{\circ} \mathrm{F}$ & Thin \\
\hline
\end{tabular}


The Epon 815-Versamid 140 mixture has about the same flexibility and texture after curing as the Epon 871-828 mixture but seems more fluid during the working time before gelation, which makes the Epon 815-Versamid 140 combination very appropriate for vacuum coil encapsulation. The mixture used for testing was 100 parts Epon 815 and 40 parts Versamid 140. Typical setup time is $4-6$ hours $275^{\circ} \mathrm{F}$ with a total cure after 24 hours.

Two Stycast epoxies were mixed and tested for shear strength. Stycast $2850 \mathrm{FT}$ (Blue) with $7 \mathrm{pph} 24 \mathrm{LV}$ hardener is a medium-thick epoxy with a room temperature cure cycle, and Stycast 2850 FT (Black) with $3.5 \mathrm{pph}$ \# 9 hardener is a thick epoxy which has a room temperature cure.

The remaining epoxies were off-the-shelf, two-part adhesives which were generally easy to mix, difficult if not impossible to outgas, and hard to pour because of their thick textures. The time from mixing to gelation was short - approximately 10-15 minutes for the Hexcel Uralite and Crest epoxies and about 8 hours for the Epotek epoxy.

The only varnish tested was an all-purpose insulating varnish, General Electric 7031, which has a room temperature cure time of about 6 hours \& $75^{\circ} \mathrm{F}$ plus 12 hours a $150^{\circ} \mathrm{F}$. GE 7031 is a one-part liquid varnish which becomes tacky in about 15 minutes when used in thin applications.

\section{B-STAGE GLASS CLOTH}

A large sample of B-stage glass cloth was obtained from Synthane Taylor of LaVerne, California for testing and evaluation. This particular sample, EF 527-5M, required a medium cure cycle, i.e., $350^{\circ} \mathrm{F}$ at 300-400 psi for $\sim 1$ hour. It should be pointed out that the medium cure cycle required for the glass cloth is obtained in industry by integrating a hydraulic press with a furnace such that the pressure and temperature can be raised simultaneously to the desired levels. Lacking a large press and furnace, we used an alternate method of applying pressure and temperature. C-clamps outfitted with strain gauges and calibrated using a load cell were used in a small oven to apply the desired pressure to 
the shear samples. Although exact control over temperature and pressure was not possible, excellent and consistent shear results were obtained. In fact, the first samples had a $360^{\circ} \mathrm{F}$ a 50 psi cure cycle and the shear strength was still higher than any of the epoxies. The refrigerated B-stage glass cloth was very easy to use and withstood severe abuse (handling, cutting, bending) with no noticeable decrease in shear strength.

\section{OTHER PARAMETERS}

'l'hree distinct tabrication techniques were used to assemble the shear samples because the epoxies were of different viscosities, the glass cloth was added to some, and the bond thickness and curing pressures were varied from sample to sample. The first technique was to use a hypodermic needle to inject the low viscosity epoxies into a mold in which the prepared samples had been placed. This method was simple and allowed the bond thickness to vary depending on the mold and adherend size. Samples $1 \mathrm{Cu}-6 \mathrm{Cu}, 1 \mathrm{SS}, 2 \mathrm{SS}$, and $1 \mathrm{Al}-7 \mathrm{Al}$ were prepared in this way.

For the thicker epoxies, a method was devised to enable the application of an epoxy, the alignment of the adherends, and the curing of the epoxy with a constant bond pressure, A Tefion sample holder was used to position the adherends and epoxy while a large spring clamp was applied to the outside adherends. The clamp allowed for thinner bond thicknesses and an approximate $210 \mathrm{KPa}$ (30 psi) cure pressure. Samples $7 \mathrm{Cu}-14 \mathrm{Cu}, 3 \mathrm{SS}-6 \mathrm{SS}$, and $8 \mathrm{Al}-13 \mathrm{Al}$ were prepared in this manner.

The third and simplest of the techniques was required for the B-stage glass cloth sample. The fabrication consisted of the adherend surface preparation as outlined on Table 3 , the cutting of the Bstage glass cloth to fit the adherend size with a pair of scissors, and the clamping of the sample with the calibrated C-clamp. The samples were then placed in the oven with the curing pressures being continuously monitored with a strain indicator. The fabrication technique for the B-stage glass cloth samples was the easiest of the techniques since no mixing, outgassing, or pouring was required and also since there was no stringent setup time. 
Several surface preparations were tried, ranging from sophisticated etching and cleaning solutions to simple abrasion and degreasing. The wide variations of surface preparations are listed in Table 2 for the varnish and epoxies samples and in Table 4 for the B-stage glass cloth samples.

A coupling agent, Dow Corning $Z$ 6020, was added to some of the Epon 871-828 and Epon 815-Versamid 140 epoxies to evaluate its effect on shear strength. Z 6020 silane is an amino-functional material widely used as a coupling agent in the fabrication of resin-glass laminates. The key to the coupling ability of this product is the dual reactivity of the silane molecule, which enables it to serve as an effective chemical bridge between the organic and inorganic. The liquid $\mathrm{z} 6020$ silane was added directly to the epoxy prior to mixing and outgassing but was applied directly to the copper adherends in a couple of the B-stage glass cloth samples, sample set number 13 .

Glass cloth was added to a few samples to act as a spacer between adherends and to possibly increase the shear strength by decreasing the thermal contraction gradient between adherend and epoxy. The glass cloth was .18mm (.007") thick, untreated, and finely woven. The cloth was simply cut to size and inserted between adherends. By nature, the Bstage glass cloth is $53.6 \%-55 \%$ glass cloth by weight.

A filler, 300-mesh fused quartz, was added to some of the Epon 871-828 and Epon 8.15-Versamid 140 epoxy samples to see the effect it might have on shear strength. It was hoped that the quartz filler would reduce the large thermal contraction gradients between the adherends and the epoxies. A $40 \%$ (by weight) addition of the fused quartz to the epoxics btill enabled simple mixing, outgassing, and pouring into the mold. Three-hundred mesh fused quartz was used since it readily dispersed throughout the epoxy and would not settle to the bottom of the mixing container. Larger sized fillers tend to stratify throughout the epoxy unless constantly stirred. The addition of the quartz filler is indicated in Tables 3 and 4.

A double lap joint (see Fig. 1) was chosen for the test configuration for ease in assembly and alignment. With this arrangement, bending 


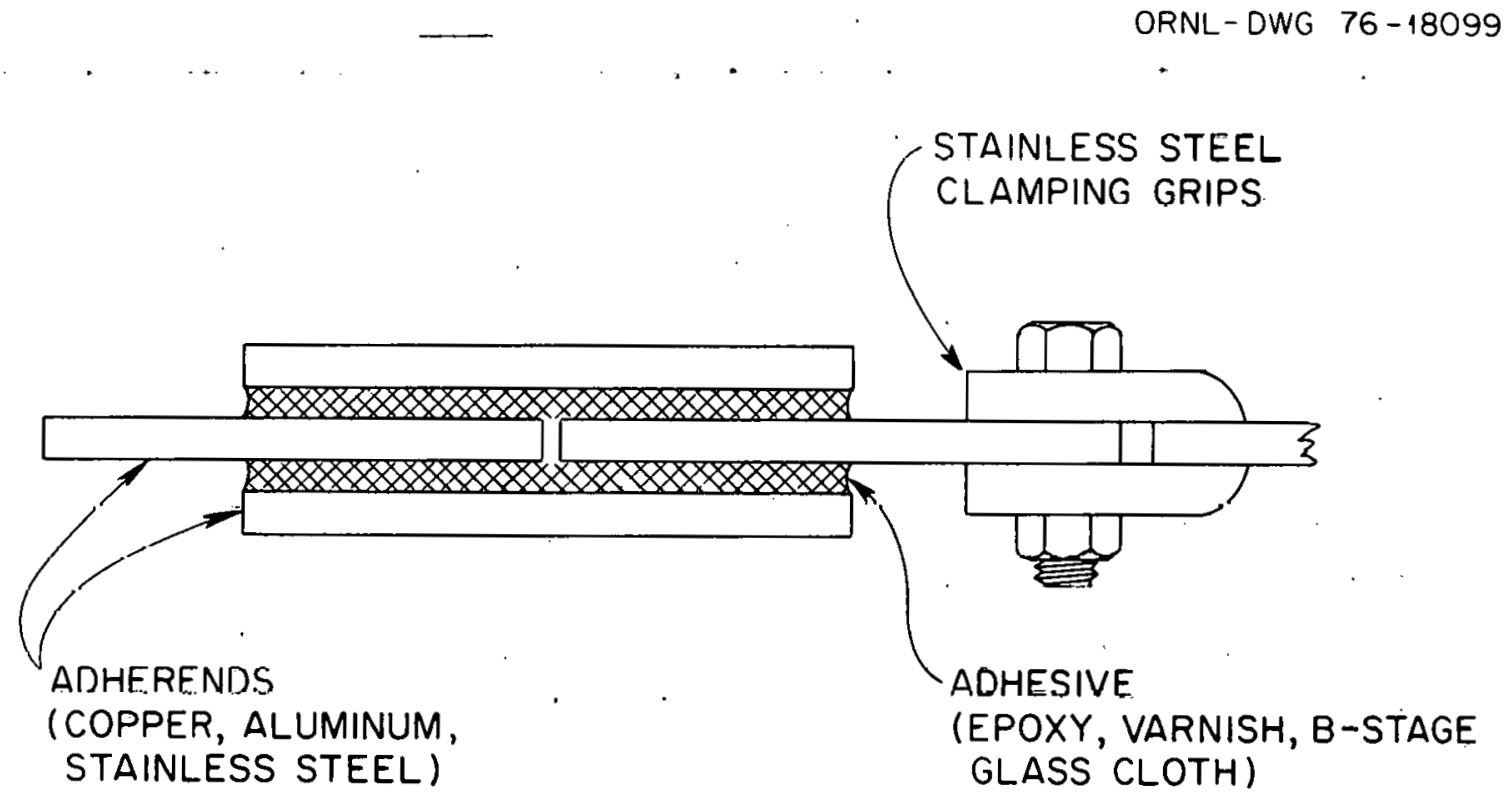

Fig. 1. Typical double lap shear sample with grips. 
Table 2. Surface Preparations of Shear Specimens

Material: Cu, ASTM B 152, L1ght Cold-Rolled

$1.59 \mathrm{~mm} \times 15.88 \mathrm{~mm} \times 50.80 \mathrm{~mm}$

$\left(1 / 16^{\prime \prime} \times 5 / 8^{\prime \prime} \times 2^{\prime \prime}\right)$

Sample Number

$1 \mathrm{Cu}$

1 - Degreased with trichloroethylene.

2 - Rinsed in distilied $\mathrm{H}_{2} \mathrm{O}$ for five minutes.

3 - Etched in a solution of:

A - Concentrated phosphorlc acid - $75 \%$

$B$ - Concentrated nitric acid - $10 \%$

C - Demineralized $\mathrm{H}_{2} \mathrm{O}-15 \%$

4 - Rinsed in distilled water and dried at room temperature.

$.2 \mathrm{Cu}$

1 - Degreased in trichloroethylene.

2 - Rinsed in distilled $\mathrm{H}_{2} \mathrm{O}$ for five minutes.

3. - Fitched in the following solution for $1 / 2$ minute:

A - Phosphoric acid - $75 \%$.

B - Sulfuric acid - $10 \%$

C - Dist1lled $\cdot \mathrm{H}_{2} \mathrm{O}-15 \%$

4 - Rinsed in distilled $\mathrm{H}_{2} \mathrm{O}$ for five minutes.

5 - Stored in desiccator in $\mathrm{CaSO}_{4}$ and pumped to $500 \mu$.

$3 \mathrm{Cu}$

1 - Used 240 lining cloth, then number 400 lining cloth until oxidized surface was removed.

2 - Stored overnight in alcohol bath.

3 - Degreased in trichloroethylene.

4 - Rinsed in alcohol.

5 - Alr dried - rubbed with facial tissue.

$4 \mathrm{Cu}$

1 - Brushed with steel brush until shiny.

2 - Abraded with $\$ 100$ (coarse) emery cloth.

3 - Immersed in a beaker of trichlorocthylene overnight.

4 - Poured off in the morning - immersed in fresh trichloroethylene - samples then removed and blotted dry.

$5 \mathrm{Cu}$

1 - Mechanically abraded using coarse emery cloth.

2 - Degreased in trichloroethylene.

3 - A1r dried at room temperature. Note: $1 / 8^{\prime \prime}$ samples instead of $1 / 16^{\prime \prime}$ for $5 \mathrm{Cu}$ only.

1 - Degreased in trichloroethylene.

2 - Air dried.

3 - Abraded with medium emery cloth, until all oxidation removed.

4 - Degreased in trichloroethylene.

5 - Air dried.

$7 \mathrm{Cu} \quad \mathrm{I}$ - Mechanfcally ahraded using coarse emery cloth.

2 - Degreased in crichloroethylene.

3 - Afr dried at ruom temperature.

$8 \mathrm{Cu}$

1 - Mechanically abraded using coarse emery cloth.

2 - Degreased in trichloroethylene.

3 - Alr dried at roon temperature.

$9 \mathrm{Cu}$

1 - Mechanically abraded using coarse emery cloch.

2 - Degreased in trichloroethylene.

3 - Air dried at room temperature.

$10 \mathrm{Cu}, 11 \mathrm{Cu}$

$120, \& .13 \%$.

1 - Mechanically abraded using coarse emery cloth.

2 - Degreased in trichloroethyliene.

3 - A1r dried at room temperature.

Material: Stainless Steel 304L ASTM A 240 Bright Cold-Rolled

$1.59 \mathrm{~mm} \times 15.88 \mathrm{~mm} \times 50.80 \mathrm{~mm}$

$\left(1 / 16^{\prime \prime} \times 5 / 8^{\prime \prime} \times 2^{\prime \prime}\right)$

ISS

1 - Degreased with trichloroethylene.

2 - Rinsed in demineralized water for five minutes.

3 - Immersed 10 minutes in the following solution:

A - 50-50 solution of $\mathrm{HCl}$ and $\mathrm{H}_{2} \mathrm{O}$

4 - Rinsed in detonized $\mathrm{H}_{2} \mathrm{O}$ at $200^{\circ} \mathrm{F}$.

5 - Dried at $200^{\circ} \mathrm{F}$. 
Table 2. Surface Preparations of Shear Specimens (cont.)

\section{Sample Number}

2SS

1 - Degreased in trichloroethylene.

2 - Rinsed in demineralized $\mathrm{H}_{2} \mathrm{O}$ for five minutes.

3 - Rinsed in the following solution for five minutes:

A - Oxalic acid - "y parts by wt.

B - Sulfuric acid - 1 part by wt.

C - Demineralized $\mathrm{H}_{2} \mathrm{O}$ - 90 parts by wt.

4 - Immersed in above solution 8-10 minutes at $180^{\circ} \mathrm{F}-190^{\circ} \mathrm{F}$.

5 - Black smut removed by brushing with a steel brush under running water.

6 - Rinsed thoroughly in demineralized water.

7 - Ringer in alcohol and dricd at room temperaluie.

35., 45 S

sกn $6,6, \operatorname{con}$

1 - Muvhantoally abraded istug cualse emtly liuth.

2 - Dugiusucu in erichloroetliylene,

3 - Atr driod at room tempcrature.

Matcrial: Al ASTM B 209 AA $1100 \mathrm{H} 14$

1. $50 \mathrm{~mm} \times 1.5,88 \mathrm{~mm} \times 50.80$
$\left(1 / 16^{\prime \prime} \times 5 / 8^{\prime \prime} \times 2^{\prime \prime}\right)$

1 - Fitched in following solution:

$200 \mathrm{ml} \mathrm{H} 2 \mathrm{O}$ (distilled)

$50 \mathrm{ml} 96 \% \mathrm{H}_{2} \mathrm{SO}_{4}$

$2 \mathrm{gr}$. sodium dichromate

2 - Degreased in trichloroethylene, rinsed in dist1lled water, then etched in above solution at $60^{\circ} \mathrm{C}$ for 12 minutes.

1 - Degreased in trichloroethylene.

2 - Rinsed in demineralized water for five minutes.

3 - Etched in a solution of :

A - Demineralized $\mathrm{H}_{2} \mathrm{O}$ - 30 parts

B - Sulfuric acid ( $96.3 \%)$ - 10 parts

C - Sodfum dichrnmate - 1 part

Immersed in above solution at $160^{\circ} \mathrm{F}$ for 10 minutes.

4 - Kinsed in demineralized $\mathrm{H}_{2}$ O for ten minutes.

5 - Stored unt1l tested in desiccator with $\mathrm{CaSO}_{4} \&$ pumped to 500u until liésted.

1 - Degreased In trichloroethylene.

2 - Rinsed in demineralized $\mathrm{H}_{2} \mathrm{O}$ for 5 minutes.

3 - Eeched in a solution of:

A - Chromic actd - 81 grame

B - Sulfuric ac1d (96.3\%) - 236 grams

C - Enough deminerallzed $\mathrm{H}_{2} \mathrm{O}$ to make 1 gallon

Immersed in above bolution at $160^{\circ} \mathrm{F}$ fur 10 mluutes.

4 - Rinsed in demineralized $\mathrm{H}_{2} \mathrm{O}$ for 5 minutes.

5 - Stored in deaiccator with $\mathrm{CaSO}_{4}$ \& pumped to 500u unt11 tested.

4AI

1 - Degreased in trichloroethylene.

2 - Rinsed in demineralized $\mathrm{H}_{2} \mathrm{O}$ for five minutes.

3 - Etched in following solution:

A - Deulueralized $\mathrm{H}_{2} \mathrm{U}$ - $2 \dot{\mathrm{U}} \mathrm{U}$ m 1

$$
\text { B - NaOH (50\% sol) - } 50 \mathrm{ml}
$$

Inmersed in above solution for 10 minutes.

4 - Rinsed in demineralized $\mathrm{H}_{2} \mathrm{O}$ for 5 minutes.

5 - Stored in desiccator with $\mathrm{CaSO}_{4}$ \& pumped to 500 unt11 tested.

5Al 1 - Degreased in trichloroethylene.

2 - Rinsed in demineralized $\mathrm{H}_{2} \mathrm{O}$ for 5 minutes.

3 - Cleaned surface with \#240\& \#600 emery cloth.

4 - Degreased in trichloroethylene.

5 - Rinsed in demineralized $\mathrm{H}_{2} \mathrm{O}$ for five minutes.

6 - Stored in desiccator.

1 - Degreased in trichloroethylene.

2 - Rinsed In demineralized $\mathrm{H}_{2} \mathrm{O}$ for five minutes.

3 - Etched in the following solution:

A - Demineralized $\mathrm{H}_{2} \mathrm{O}$ - 30 parts

B - Sulfurlc acid - 10 parts

C - Sodium dichromate - 1 part 
Table 2. Surface Preparations of Shear Specimens (cont.)

Sample Number

Immersed In above solution $160^{\circ} \mathrm{F}$ for 10 minutes - then stored

In desiccator with $\mathrm{CaSO}_{4}$ \& pumped to $500 \mu$ until tested.

$7 \mathrm{Al}$

1 - Degreased with trichloroethylene.

2. - Rinsed in demineralized $\mathrm{H}_{2} \mathrm{O}$ for five minutes.

3 - Rinsed in methyl alcohol.

4 - Dried at room temperature.

5 - Etched in the following solution:

A - Demineralized $\mathrm{H}_{2} \mathrm{O}$ - 30 parts

B - Sulfuric ac1d $(96.3 \%)$ - 10 parts

C - Sodium dichromate - 1 part

6 - Rinsed in demineralized $\mathrm{H}_{2} \mathrm{O}$ for 5 minutes.

7 - Rinsed in methyl alcohol and dried.

Size: $\quad 3.5 \mathrm{~mm} \times 15.88 \mathrm{~mm} \times 50.80 \mathrm{~mm}$

$$
\left(1 / 8^{\prime \prime} \times 5 / 8^{\prime \prime} \times 2^{\prime \prime}\right)
$$

8Al, 9Al

$10 \mathrm{Al}$ \& $11 \mathrm{Al}$

1 - Mechanically abraded using coarse emery cloth.

2 - Degreased in trichloroethylene.

3 - Air dried at room temperature 
Table 3. Shear Test Results of Epoxies

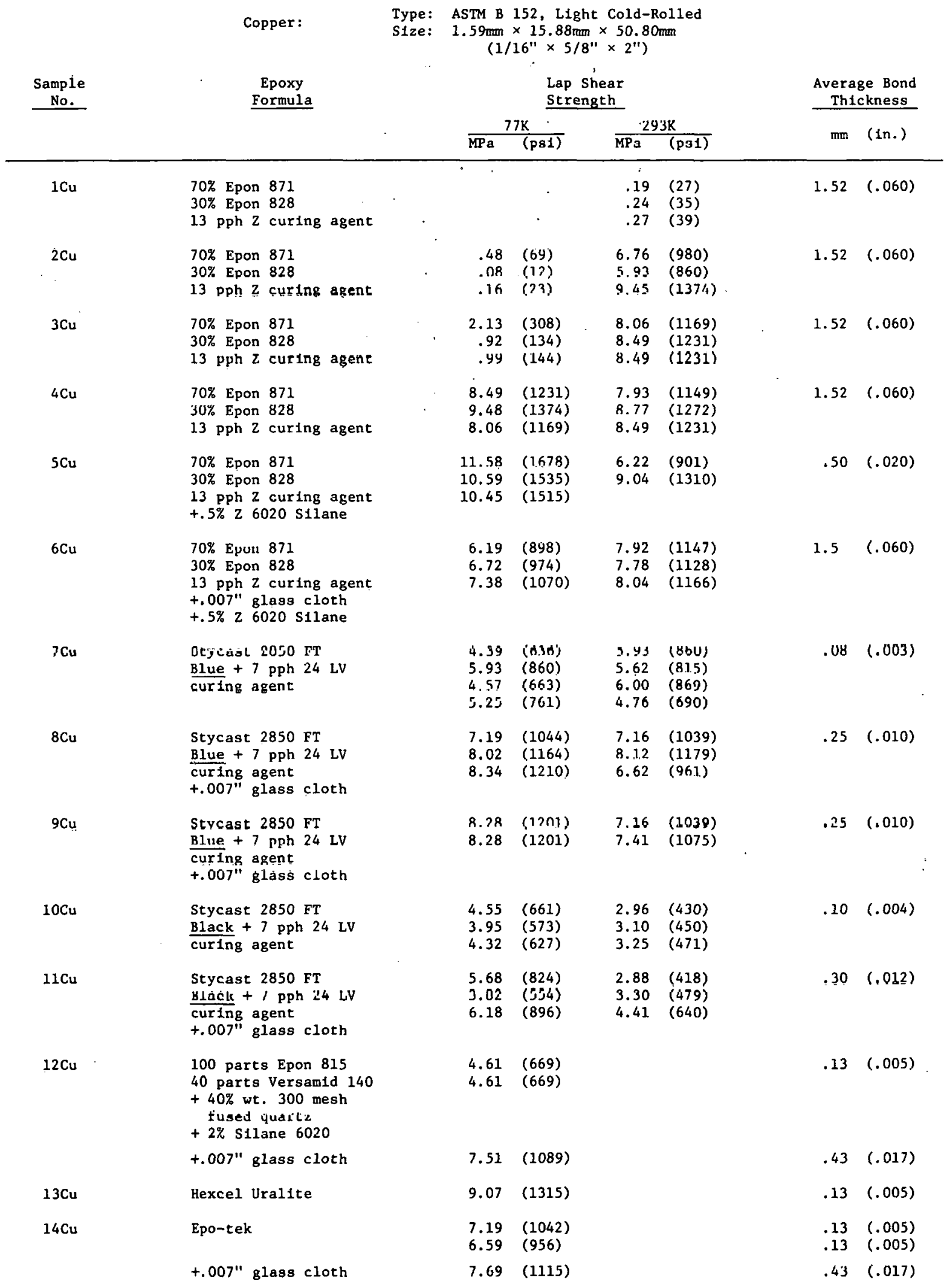


Table 3. Shear Test Results of Epoxies (cont.)

Stainless Steel:

\begin{tabular}{|c|c|}
\hline $\begin{array}{c}\text { Sample } \\
\text { No. }\end{array}$ & $\begin{array}{c}\text { Epoxy } \\
\text { Formula }\end{array}$ \\
\hline $1 S S$ & $\begin{array}{l}70 \% \text { Epon } 871 \\
30 \% \text { Epon } 828 \\
13 \text { pph } Z \text { curing agent }\end{array}$ \\
\hline $2 \mathrm{SS}$ & $\begin{array}{l}70 \% \text { Epon } 871 \\
30 \% \text { Epon } 828 \\
13 \text { pph Z curing agent }\end{array}$ \\
\hline $3 \mathrm{SS}$ & $\begin{array}{l}70 \% \text { Epon } 871 \\
30 \% \text { Epon } 828 \\
13 \text { pph } 2 \text { curing agent } \\
+40 \% \text { wt. } 300 \text { mesh } \\
\text { fused quartz } \\
+1 \% \text { S1lane } 6020 \\
+.007^{\prime \prime} \text { glass cloth }\end{array}$ \\
\hline
\end{tabular}

4SS

5SS

Aluminum:

$1 \mathrm{~A} 1$

$2 \mathrm{Al}$

$3 \mathrm{Al}$

$4 \mathrm{Al}$

100 parts Epon 815

40 parts Versamid 140

$+1 \%$ S1lane 6020

$+.007^{\text {th }}$ glass cloth

100 parts Epon 815

40 parts Versamid 140

$+40 \%$ wt. 300 mesh

fused quartz

$+1 \%$ Stlane 6020

$+.007^{\prime \prime}$ glass cloth

100 parts Epon 815

40 parts Versamid 140

$+40 \%$ wt. 300 mesh

fused quartz

$+2 \%$ S1lane 6020

$+.007 "$ glass clutl.

$70 \%$ Epon 871

$30 \%$ Epon 828

13 pph 2 curing agont

$30 \%$ Epon 828

13 pph 2 curing agent

$30 \%$ Epon 871

L3 pph 2 curing agent

$10.94 \quad(1587)$

$43 \quad(.017)$

$11.12 \quad(1612)$

$.43(.017)$

$17.14 \quad(2485)$

$.43(.017)$

$11.99^{\circ}(1739)$

11.99 (1739)

$13(.005)$

9.41 (1365)

$.13(.005)$

16.94 (2457)

$.13(.005)$

$.43(.017)$

$15.17(2200)$

$.43(.017)$

6.57 (953)

$.13(.005)$

6.57 (953)

$.13(.005)$

11.59 (1680)

$.43(.017)$

12.57 (1822)

$.43(.017)$

7.91 (1147)

$.13(.005)$

$.13(.005)$

Type: ASTM B 209 AA $1100-\mathrm{H} 14$

S1ze: $\quad 1.59 \mathrm{~mm} \times 15.88 \mathrm{~mm} \times 50.80 \mathrm{~mm}$ $\left(1 / 16^{\prime \prime} \times 5 / 8^{\prime \prime} \times 2^{\prime \prime}\right)$

$\begin{array}{rrrr}4.67 & (677) & 5.09 & (738) \\ 5.52 & (800) & 5.52 & (800) \\ 6.23 & (903) & >5.58 & (8 \cap 9)\end{array}$

$1.52(.060)$

$4.82 \quad(700)$

$1.52(.060)$

$3.58 \quad(520)$

$>5.65 \quad(820)$

$1.52(.060)$

$>5.44 \quad(789)$

$>5.23(759)$

$>5.09$ (738)

$1.52(.060)$

$13 \mathrm{pph} 7$. curting agent 
Table 3. Shear Test Results of Epoxies (cont.)

Aluminum: $\quad$ Type: ASTM B 209 AA 1100 - H14

Size: $1.59 \mathrm{~mm} \times 15.88 \mathrm{~mm} \times 50.80 \mathrm{~mm}$

$$
\left(1 / 16^{\prime \prime} \times 5 / 8^{\prime \prime} \times 2^{\prime \prime}\right)
$$

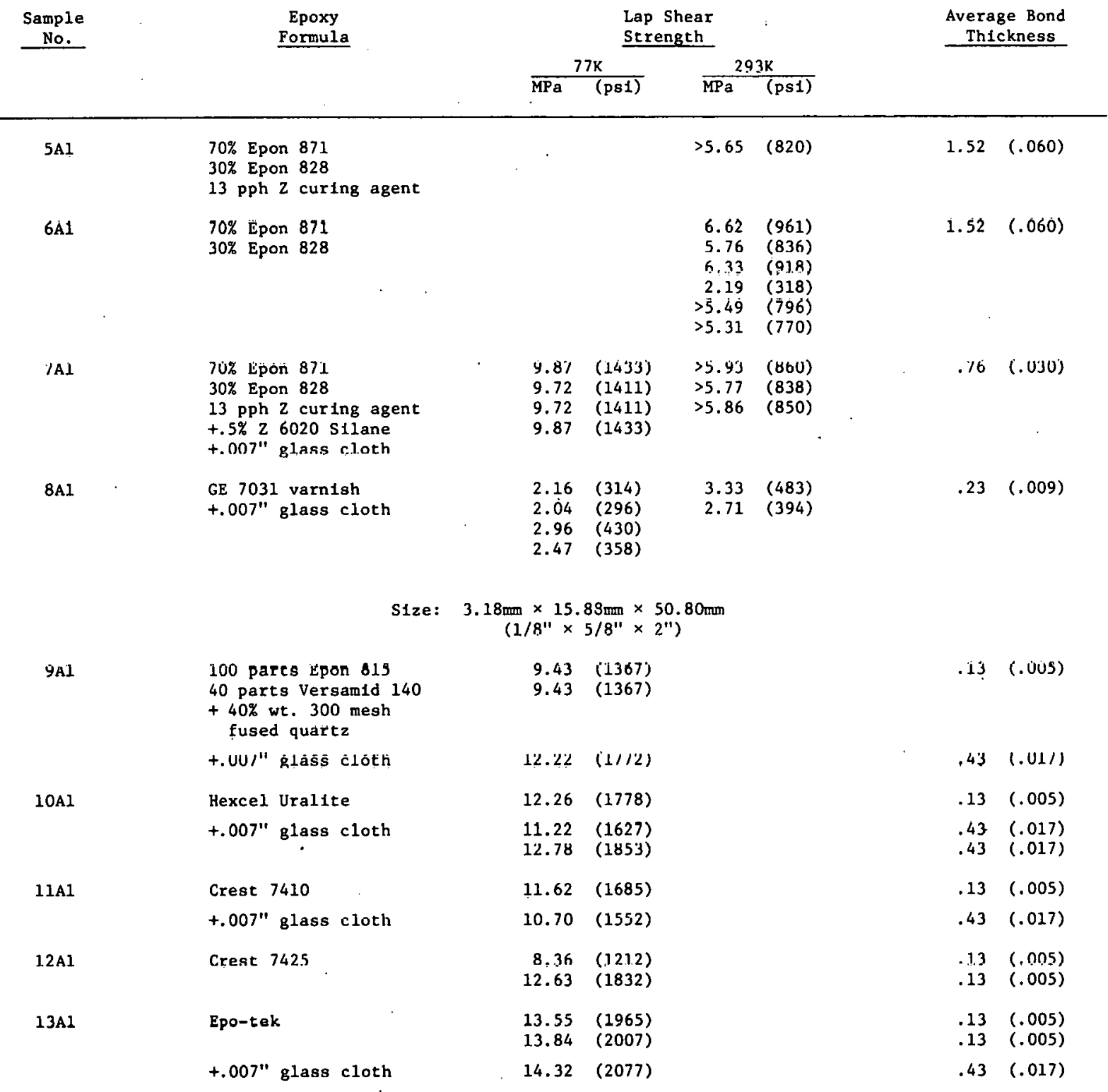


Tahle 4. Shear Test Results of B-Stage Glass Cloth

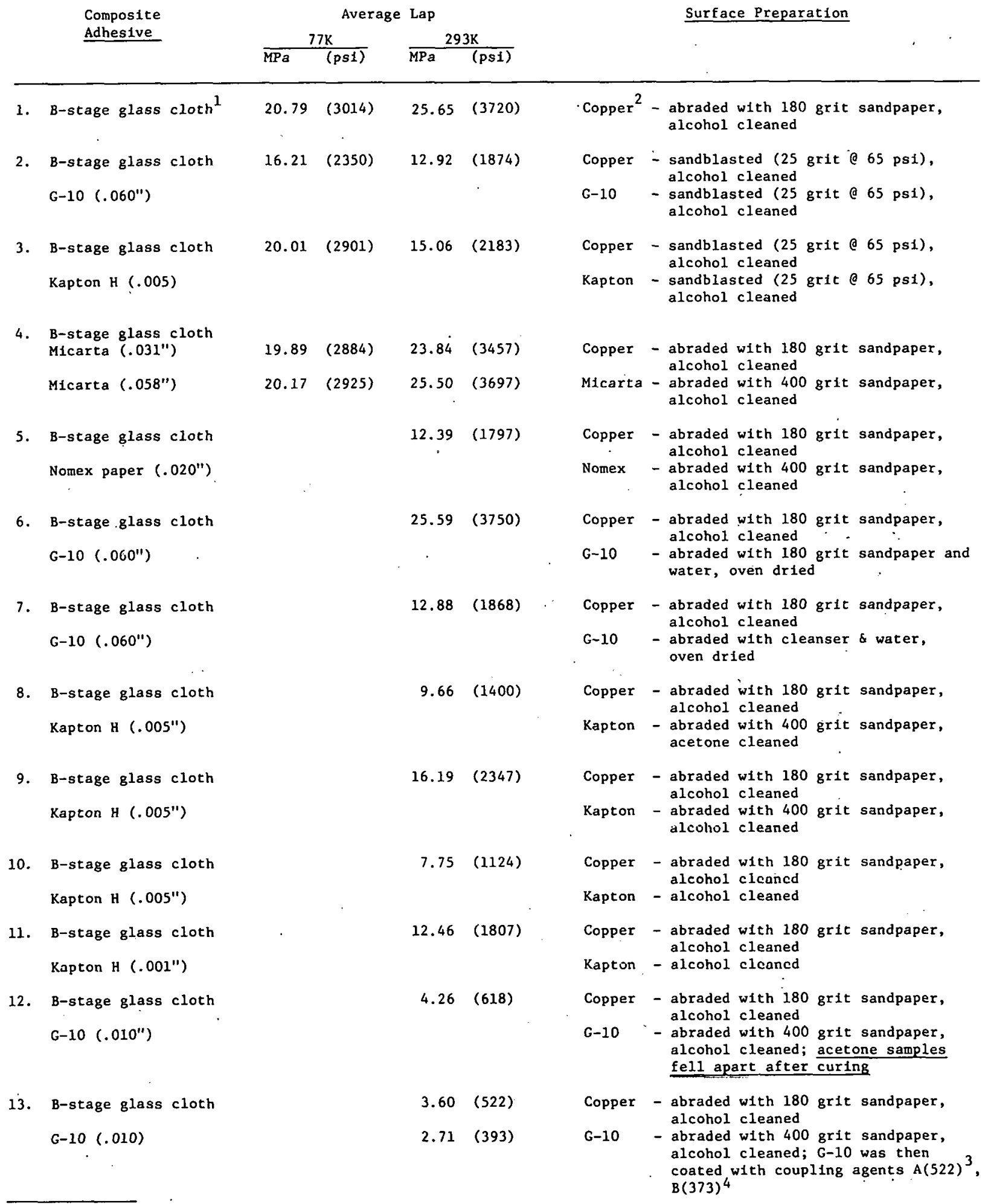

1. Synthane Taylor EF 527-5m, glass B-stage cloth; samples were cut to size and used as recelved; medium cure cycle was used as advised by Synthane laylor $\left(350^{\circ} \mathrm{F}, 300-400\right.$ ps $\perp$ pressuse [ut 1 livur).

2. OFHC Copper, $5 / 16^{\prime \prime} \times 1 / 4^{\prime \prime} \times 2^{\prime \prime}$.

3. Silane 26040 Coupling agent, Dow Corning.

4. Silane $Z 6020$ Coupling agent, Dow Corning. 
moments on the sample are kept to a minimum. Since the lap shear area is double that of a simple lap joint, it was necessary to apply twice the load. The tensile loads were applied and recorded using a Hounsfield Tensometer. The quick grips provided with the instrument were used at room temperature while special clamping grips, which had to be designed for use in the liquid nitrogen tank, worked successfully at $77 \mathrm{~K}$.

\section{RESULTS}

The results of the lap shear tests, listed in l'able 3 for the varnish and epoxies and in Table 4 for the B-stage glass cloth, include the adhesive type, adherend type, lap shear strength at $77 \mathrm{~K}$ and $293 \mathrm{~K}$, and average bond thickness. All the epoxy samples tested are listed, and no attempt has been made to average the results. Large variations, in general, can be explained by misalignment of adherends during fabrication. The available small amounts of the Hexcel, Epo-tek, Crest, and Versamid epoxies limited the sample fabrication to two copper and two aluminum samples, which were tested at liquid nitrogen temperatures only.

Many of the aluminum adherends used in the epoxy tests fractured at room temperature because the lap shear strength of the specific epoxy was not known at the time of assembly. The liquid nitrogen shear strength values are valid because the shear strength of the specific epoxy either decreased or remained constant from $293 \mathrm{~K}$ to $77 \mathrm{~K}$, whereas the ultimate tensile strength of the aluminum increased. Nonetheless, the room temperature values are still valuable as low minimum shear strengths. Fractured aluminum adherend samples are indicated by a greater than sign ( $>$ ) indicating that the lap shear strength of the epoxy was higher than the ultimate tensile strength of the aluminum adherend at room temperature. Once the problem was identified thicker aluminum adherends were used.

The highest shear strength of the epoxies was obtained with the Epon 871-828 mixture plus quartz, silane, and glass cloth and using stainless steel adherends. The same epoxy without the glass cloth had about a $35 \%$ reduction in shear strength. Only two other epoxies had a shear strength greater than $13.8 \mathrm{MPa}$ (2000 psi): an Epon 815-Versamid 140 epoxy (\# 4SS) and the Epo-tek epoxy (\# 13A1). The addition of the 
Dow Corning Silane Z 6020 to the Epon 871-828 epoxies increased shear strength about ten-fold between room temperature and liquid nitrogen. In most all cases, the addition of glass cloth increased the shear strength from $1 \%$ to $37 \%$ depending on the epoxy and the adherend type. With a similar testing epoxy and cryogenic environment, the stainless steel-epoxy samples had the highest shear strengths, the aluminum-epoxy next, and copper-epoxy the lowest shear strength.

Average lap shear strengths are shown for the B-stage glass cloth because of the small variation in the values (about 10\%) and the large number of samples tested. Room temperature lap shear tests were performed first and the most promising samples were later tested in liquid nitrogen. B-stage glass cloth was used in most of the samples with other insulation materials because it is in this composite adhesive form in which it will most likely be utilized. By itself, the cured B-stage glass cloth is porous when viewed under a microscope, but with the addition of an Insulating film between layers of the glass cloth, electrical insulation is guaranteed with 1ittle loss in mechanical strength at $77 \mathrm{~K}$.

In general, the copper adherends needed to be abraded or sandblasted to remove the oxidation layer and then wiped with or stored in alcohol until fabrication. Each of the insulations required a particular surface preparation for maximum adhesion to the B-stage glass cloth. Good adhesion was found in all the insulations except G-10 by sandblasting or abrading the insulation surface and then cleaning with alcohol; G-10 required a simple abrasion with water and oven drying for best results. Acetone cleaning in every case greatly reduced the shear strength; in fact, the acetone cleaned G-10 samples fell apart after curing.

The results in Table 4 show that the samples fabricated with the B-stage glass cloth only had the highest strengths at $77 \mathrm{~K}$ and $293 \mathrm{~K}$, with the actual strength decreasing about $20 \%$ from $293 \mathrm{~K}$ to $77 \mathrm{~K}$. The Micarta B-stage glass cloth composite had the next highest values with a similar $20 \%$ decrease in strength from $293 \mathrm{~K}$ to $77 \mathrm{~K}$. The G-10 and the Kapton composites with B-stage glass cloth had acceptable strengths at $293 \mathrm{~K}$ but shear strength increased about $30 \%$ froin $293 \mathrm{~K}$ to $77 \mathrm{~K}$. 


\section{CONCLUSIONS}

The adhesive with the highest lap shear strength at both room and liquid nitrogen temperatures was a B-stage glass cloth bonded to copper. Shear strengths of $25.65 \mathrm{MPa}$ at room temperature and $20.79 \mathrm{MPa}$ in liquid nitrogen were measured for the $\dot{B}$-stage glass cloth.

The highest lap shear strength of the epoxies was an Epon 871-828 formulation with a $17.4 \mathrm{MPa}$ shear strength at $77 \mathrm{~K}$. An Epon 815-Versamid 140 formulation was next with a shear strength of $16.94 \mathrm{MPa}$ at $77 \mathrm{~K}$. Both of these samples used stainless steel for the adherends.

Sophisticated etching solutions and cleaning techniques did not substantially increase the shear strength over simple abrasion and degreasing in trichloroethylene. In relation to coil fabrication, a sandblasting unit with a spray degreaser would be sufficient for surface preparation. It would be necessary to provide an inert atmosphere around the cleaned surface if an extended period of time elapsed between surface preparation and coating or winding to avoid possible oxidation or contaminant buildup.

It is thought that by further increasing the percentage of silane coupling agent, by adding to the epoxy other fillers which would more closely match the adherend thermal contraction coefficient, and by differing the percentage of glass cloth, epoxy combinations with larger shear strengths can be found. 
INTERNAL DISTRIBUTION

ORNL/TM-5658

1. W. C. Anderson

2. J. K. Ballou

3. R. L. Brown

4. E. H. Bryant

5. P. B. Burn

6. W. D. Cain

7. D. D. Cannon

8. J. F. Clarke

9. F. L. Culler

10. L. Dresner

11. J. F. E11is

12. W. A. Fietz

13. W. H. Gray

14. P. N. Haubenreich

15. J. P. Kois

16. G. G. Kelley

17. C. G. Lawson

18. C. J. Long

19. H. M. Long

20. J. K. Lovin

21-25. M. S. Lubell (5)

26. J. W. Lue

27. J. N. Luton

28. H. C. McCurdy
29. J. R. Miller

30. R. V. Miskel.L

31. O. B. Morgan

32. H. Pih

33. H. Postma

34. M. Roberts

35. M. W. Rosenthal

36. R. E. Schwall

37. T. E. Shannon

38. S. S. Shen

39. J. E. Simpkins

40. D. Steiner

41. W. C. T. Stoddart

42. P. B. Thompson

43. P. L. Walstrom

44. H. T. Yeh

45. A. Zucker

46-47. C. R. Library (2)

48. CTR Reports Office

49. Document Ref. Section

50-51. Lab Records Dept. (2)

52. Lab Records, ORNL, R.C.

53. Patent Office

54-55. T. D. Library (2)

\section{EXTERNAL DISTRIBUTION}

56. E. Adam, Airco, 100 Mountain Avenue, Murray Hill, NJ 07974.

57. J. W. Beal, DMFE, ERDA, Mail Stop G-234, Washington, DC 20545.

58. R. W. Boom, 513 Engineering Research Building, University of Wisconsin, Madison, WI 53706.

59. D. L. Coffey, American Magnetics Inc., P. O. Box R, Oak Ridge, TN 37830.

60. D. N. Cornish, Lawrence LIvermore Laboratory, P. 0. Box 808, Livermore, CA 94550.

61. M. D'Agostino, Grumman Aerospace Corp., Bethpage, NY 11714 .

62. J. E. Darby, Jr., CTR Program, D208, Argonne National Laboratory, 9700 South Cass Ayenue, Argonne, IL 60439.

63. R. W. Derby, Magnetics Engineering Associates, 247 Third Street, Cambridge, MA 02141.

64. Director, Research \& Technical Support Division, ERDA, Oak Ridge Operations, Oak Ridge, TN 37830.

65. R. W. Fast, Manager, Experimental Facilities, National Accelerator Laboratory, P. 0. Box 500, Batavia, IL 60510.

66. J. J. Ferrante, General Electric Co., Schenectady, NY 12345.

67. J. File, Princeton University, Plasma Physics Laboratory, Princeton, NJ 08540.

68. W. S. Gilbert, Lawrence Berkeley Laboratory, University of California, Berkeley, CA 94120 . 
69. R. W. Gould, Dept. of Applied Physics, California Institute of Technology, Pasadena, CA 91109.

70. H. Grad, Courant Institute, New York University, 251 Mercer Street, New York, NY 10012.

71. E. Gregory, Airco, 100 Mountain Avenue, Murray Hill, NJ 07974.

72. W. V. Hassenzah1, Los Alamos Scientific Laboratory, P. O. Box 1663 Los Alamos, NM 87544.

73. C. D. Henning, DMFE, ERDA, Mail Stop G-234, Washington, DC 20545.

74. G. K. Hess, DMFE, ERDA, Mail Stop G-234, Washington, DC 20545.

75. C. K. Jones, Manager, Cryogenic Research Laboratory, Westinghouse Electric Corporation, R \& D Center, Pittsburgh, PA 15235.

76. E. E. Kintner, DMFE, ERDA, Mail Stop G-234, Washingtun, DC 20545.

77. H. L. Laquer, Los Alamos Scientific Jahoratory, P. O. Box 1663, Los Alumoe, NM 87544.

78. C. Laverick, 543 Hampshire Lane, Boling Brook, IL 60439.

79. J. A. Mayha11, Lockheed, P. O. Box 1103, Huntsville, AL 35807.

80. D. B. Montgomery, MIT, National Magnet Laboratory, 170 Albany Street, Cambridge, MA 02139.

81. F. Moon, Dept. of Theoretical \& Applied Mechanics, Cornell University, Tthaca, NY 14850 .

82. R. W. Moses, Jr., University of Wisconsin, Madison, WI 53706.

83. J. R. Powel1, Brookhaven National Laboratory, Upton, NY 11973.

84. J. R. Purcell, General Atomic Company, P. 0. Box 81608, San Diego, CA 92138 .

85. P. Reardon, PPPL, Princeton Univ., P. O. Box 451, Princeton, NJ 08540.

86. J. D. Rogers, Q-26, Los Alamos Scientific Laboratory, P. O. Box 1663, Los Alamos, NM 87544.

87. D. J. Rose, Dept. of Nuclear Engineering, Massachusetts Institute of Technology, Cambridge, MA 02139.

88. C. H. Rosner, Intermagnetics General Corp., Charles Industrial Park, New Karner Road, Guilderland, NY 12084.

89. W. B. Sampson, Brookhaven National Laboratory, Upton, Long Island, NY 11973.

90. Z, J. J. Stek1y, Magnetic Corporation of American, 179 Bear Hill Road, Wa1tham, MA 02154.

91. B. P. Strauss, Ferm1 National Accelerator Laboratory, P. 0. Box 500 , Batavia, IL 60510 .

92-118. TIC, Oak Ridge, TN 37830, (27)

119. C. E. Taylor, Lawrence Livermore Laboratory, P. 0. Box 808, L-384 Livermore, CA 94551.

120. R. Thomas, General Atomic Company, P. 0. Box 81608, San Diego, CA 92138 .

121. C. von Keszycki, Grumman Aerospace Corp., Research Center, Building 26, Bethpage, NY 11714.

122. S. T. Wang, Argonne National Laboratory, 9700 South Cass Avenue, Argonne, IL 60439.

123. J. M. Wilitams, DMFE, ERDA, Mail Stop G-234, Washington, DC 20545.

124. S. L. Wipf, Q-26, Los Alamos Scientific Research Laboratory, P. 0. Box 1663, Los Alamos, NM 87544.

125. J. Wong, Supercon, Inc., 9 Erie Drive, Natick, MA 01760.

126. H. H. Woodson, Chairman, Dept. of Electrical Engineering, University of Texas at Austin, Austin, TX 78712.

127. E. J. Ziurys, DMFE, ERDA, Mail Stop G-234, Washington, DC 20545. 